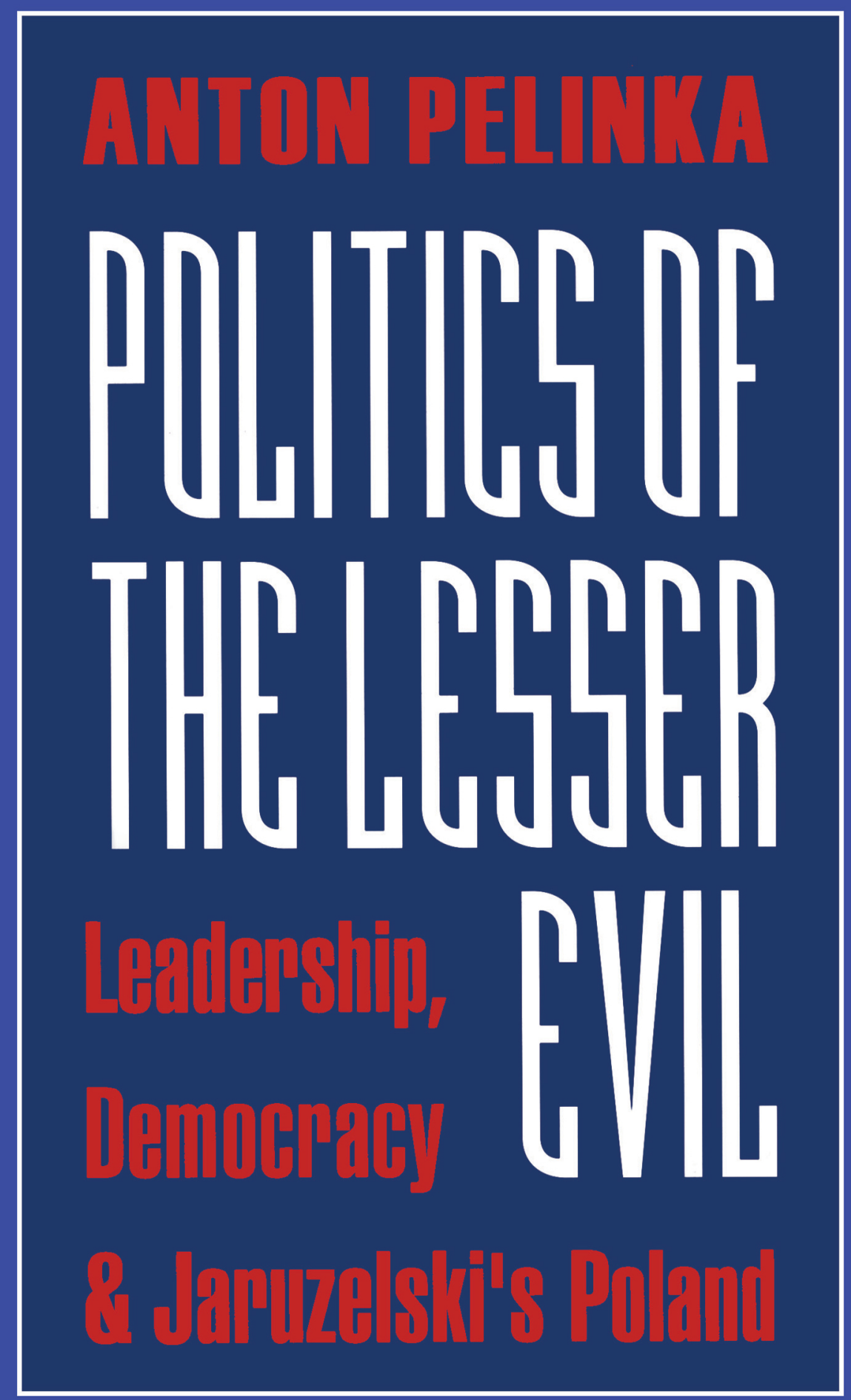



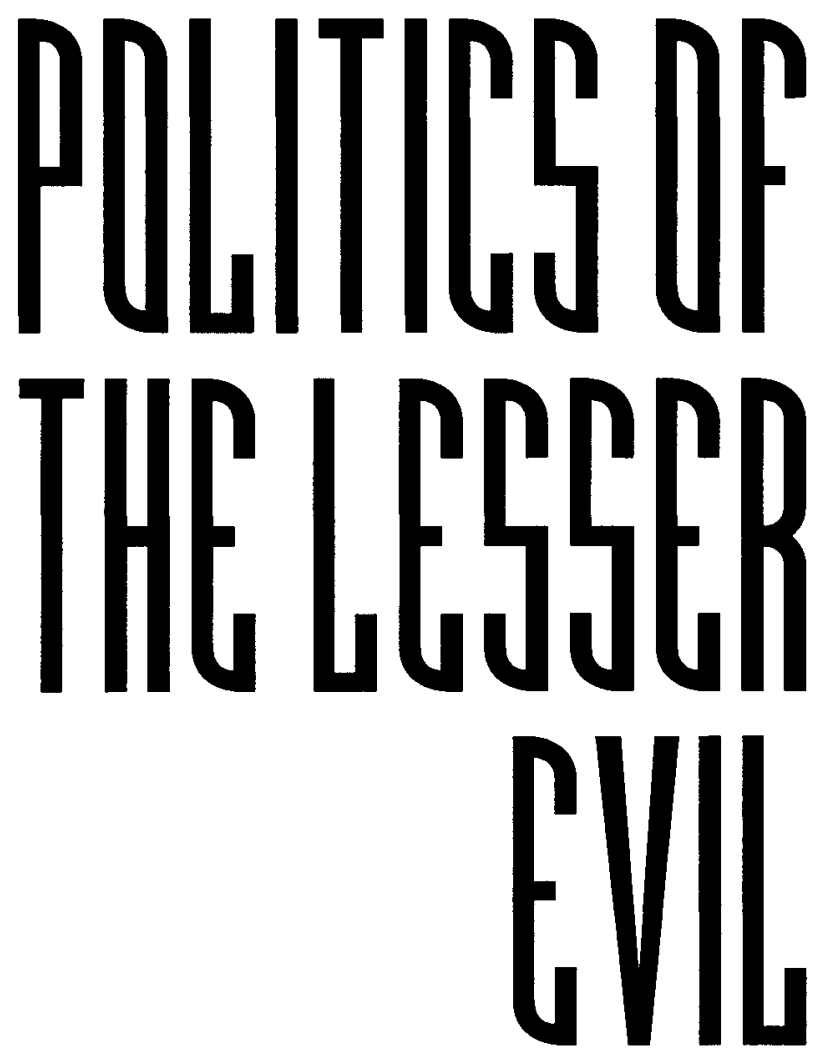


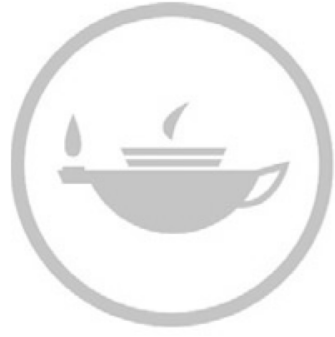

Taylor \& Francis
Taylor \& Francis Group http://taylorandfrancis.com 


\section{ANTON PELWKA}
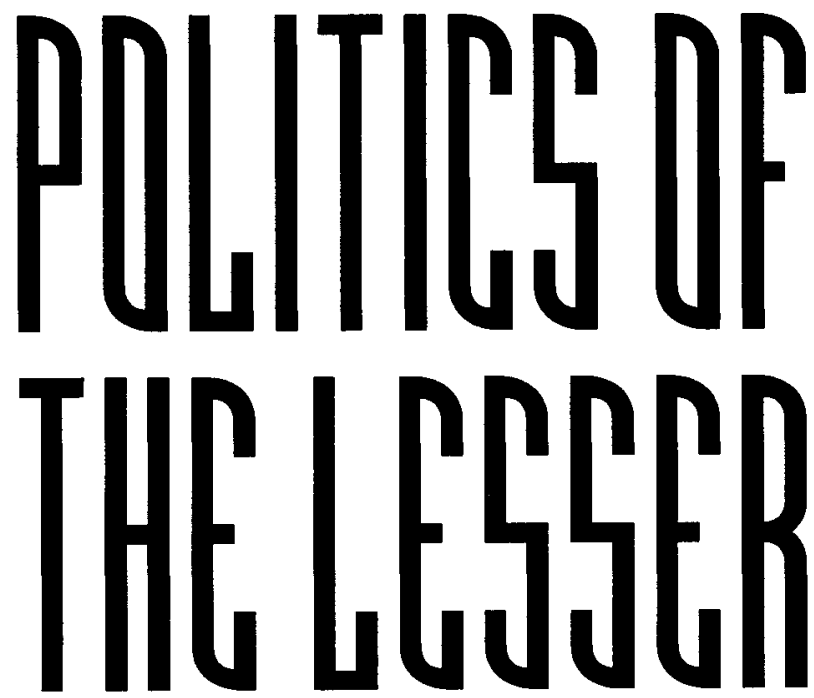

Leadership,

Democracy

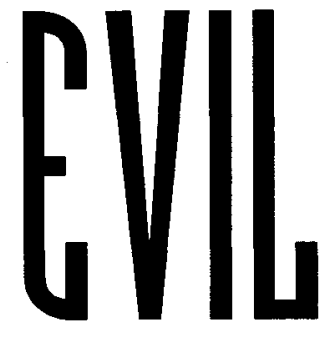

\& Jaruzelski's Poland

Routledge
Taylor \& Francis Group

LONDON AND NEW YORK 
First published 1999 by Transaction Publishers

Published 2017 by Routledge

2 Park Square, Milton Park, Abingdon, Oxon OX14 4RN

711 Third Avenue, New York, NY 10017, USA

Routledge is an imprint of the Taylor \& Francis Group, an informa business

Copyright $(1999$ by Taylor \& Francis

All rights reserved. No part of this book may be reprinted or reproduced or utilised in any form or by any electronic, mechanical, or other means, now known or hereafter invented, including photocopying and recording, or in any information storage or retrieval system, without permission in writing from the publishers.

Notice:

Product or corporate names may be trademarks or registered trademarks, and are used only for identification and explanation without intent to infringe.

Library of Congress Catalog Number: 97-51254

\section{Library of Congress Cataloging-in-Publication Data}

Pelinka, Anton, 1941-

Politics of the lesser evil : leadership, democracy, and Jaruzelski's Poland / Anton Pelinka.

p. $\mathrm{cm}$.

Includes bibliographical references (p. ) and index.

ISBN 1-56000-367-7 (acid-free paper)

1. Jaruzelski, W. (Wojciech) 2. Democracy. 3. Leadership.

4. Poland-Politics and government-1980-1989. I. Title.

DK4435.J37P454 1998

$943.805^{\prime} 6^{\prime} 092-\mathrm{dc} 21$

97-51254

CIP

ISBN 13: 978-1-56000-367-0 (hbk) 


\section{Table of Contents}

$\begin{array}{ll}\text { Foreword } & 9\end{array}$

$\begin{array}{ll}\text { 1. On Leadership } & 11\end{array}$

2. Jaruzelski I: On the Gravity of one - of any Political Decision

Martial law - The end of dual rule - The parameters

- Purgatory instead of hell - A particular type of

dictatorship - Jaruzelski as leader

3. On the Illusion of Democratic Leadership

The fantasy of democracy - Heroes and (or) managers Politics and policies - Leadership as an exception to the rule

4. An Impossible Encounter - The First

"But the art of policy is to create a calculation of the risks and rewards that affect the adversary's calculations."

5. On the Tendency to Ban Machiavelli to Hell

The conversation in hell - Machiavelli, the subversive man of reason - No special moral for politics -

Politicians as scapegoats

6. On the Limits of Idealism

Democracy and fundamentalism - Stalin as a realist Hitler as an idealist - American idealism - Idealism à la Lyndon Johnson - Kennedy: Idealism as public relations

7. Charisma

8. On the Attempts to Tame a Myth

Is personality really everything? - Charisma as product

- The erosion of all ethics - leadership as a (necessary?)

illusion - Vietnam

9. On the Skepticism Toward Too Much Democracy

Constitution against tyranny - The Fear of the majority -

Lincoln's contradictions - Babeuf's Impatience - Democracy

from above? 
10. On the Unavoidability of Lying

The Galilei strategy - Joan of Arc or a politician? -

The art of deception - Dr. Jekyll and Mr. Hyde

- Dr. Strangelove

11. On the Misery of Collaboration

The tragedy of the Jewish councils - Collaboration as a lesser evil - Philippe Pétain - The collaboration of Azdak and of Schwejk - Collaboration is not always collaboration - Collaboration as an attempt at political action

12. On the Presumption of Objectivity

Dirty hands - The script of world history -

The longing for categories - All orthodoxies are alike

13. On the Ambiguity of Difference

The stubbornness of Karl Kraus - Partial fascism as a lesser evil - Between devil and Beelzebub - Churchill:

Political capability through differentiation - Churchill:

More than Realpolitik - Not every appeasement is alike

14. On the Amorality of Foreign Policy

Wilson: Principles without strategy - Roosevelt:

Principles and strategy - Johnson: No principles and no strategy - Nixon: Strategy without principles

15. On the Logic of Leninism

Just is the opposite of just - Professional revolutionaries and leadership - Lenin and Stalin as empiricists -

Absolute politics becomes non-politics

16. On the True Nature of Personal Leadership

Leadership as mass murder - Excessive leadership -

Distancing as style - The freedom from having to learn

- The question of succession - To chain or unchain

leadership?

17. On the Necessity of Limiting Evil

The category of evil - The function of utopia -

The "lesser evil" as justification - Franz Jägerstätter

18. On the Longing for William Tells and Robin Hoods

Italy, Japan, and Switzerland as exceptions -

The invention of heroes - Leadership as spectacle

- Real functions of monarchies 
19. On the Necessity of Becoming a Parvenu

The identities forced on Rosa Luxemburg - Pariah against

one's will, parvenu as a necessity - The function of

Zionism - "Black" and "white" — Benjamin Disraeli

20. An Impossible Encounter - The Second

"What is the object of our thought? Experience!

Nothing else!"

21. On the Democratic Dissolution of Politics in General Inner- or other-directed leadership - Public versus private - Politics as knowledge of climate - Autopoiesis:

No one rules - The fiction of the "people"

22. On the Transformation of the People into the Marketplace The people or "one people" - McNamara's management

- The market as anti-utopia - Fulbright's logical contradictions - "People" means exclusion The stubbornness of the woodworms

23. The Cockpit

24. On the Possibility of Intellectual and Moral Leadership Mahatma Gandhi and Martin Luther King, Jr. -

The "guilty conscience" - The refusal to take office as a prerequisite of leadership - The impatience of the

Bolsheviks - Angelo Guiseppe Roncalli

25. Jaruzelski II: On the Arbitrary Nature of Historical Perception

The viewpoint of the opposition - The Soviet viewpoint

- "It is time" - The Bishops - A new type of

transformation - Katyn - The Commissar's dilemma -

Hero or traitor?

26. Bibliography

Index of Persons 


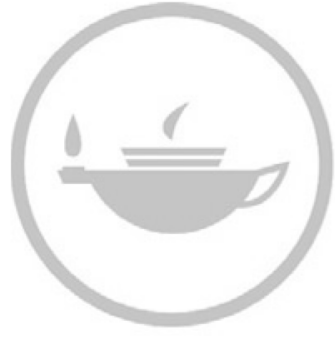

Taylor \& Francis
Taylor \& Francis Group http://taylorandfrancis.com 


\section{Freword $^{\text {orw }}$}

The German edition of this book appeared in 1996: "Jaruzelski oder die Politik des kleineren Übels: Zur Vereinbarkeit von Demokratie und 'leadership"' (Frankfurt am Main: Peter Lang Verlag). Since that time, the debate over the role of General Jaruzelski has continued. In Poland this debate has the character of a political fight. After its victory in the election of 1993, the "leftist" majority of the Sejm had ended the parliamentary investigation into Jaruzelski's behavior during the period of martial law. Legal investigations into the General's role in the crackdown on the strike movements in 1970, among other things, came to nothing. The question of whether or not a military invasion of the Red Army was imminent remains unanswered. What is certain is that there was no direct threat from Moscow. It is just as certain that the possibility of a Soviet intervention was a threat to be reckoned with.

Jaruzelski's position in 1981 will continue to be the subject of controversy both in Poland and outside that country. Yet the role Jaruzelski played within the framework of Gorbachev's policies beginning in 1985 has met with increasing interest in scholarly analysis. Jaruzelski's decision to allow the first free elections in a state of the Warsaw Pact accelerated the reforms that ultimately led to the end of the Soviet-type systems in Europe, to German unification and to the collapse of the Warsaw Pact and of the Soviet Union (Zelikow, Rice 1995, 70, 88; Maier 1997, 124, 182-185). The round table conferences between Jaruzelski and Solidarity became the lever for western, liberal democracy. With that, General Jaruzelski's Poland became the model for the transition of political systems.

The task of this book is not to deliver a final judgment on Wojciech Jaruzelski. Jaruzelski serves as a model, as an interesting case study that clarifies the essence of leadership, particularly the tendency toward the incompatibility of leadership and democracy. Jaruzelski's status as an individual who will remain controversial only serves to emphasize the paradigmatic character of his behavior.

I thank Irving Louis Horowitz for including this book in the publishing program of Transaction Press. I thank Renée Schell for translating the text from German into English and for her spirit of cooperation. I thank Ellen Palli for her fine technical preparation of the English text. 


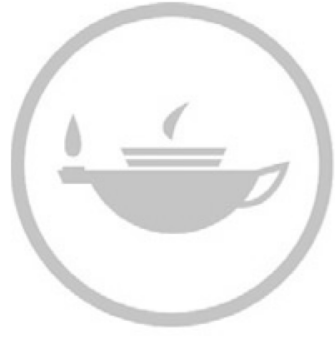

Taylor \& Francis
Taylor \& Francis Group http://taylorandfrancis.com 


\section{On Leadership}

This is a book about Wojciech Jaruzelski, about the role that he played in 1981 and about the role that was played to him in 1989. But these observations are not only and not even primarily intended as an historical representation. Rather, the person of the Polish General, Prime Minister, Party Secretary and President serves as an example of what it means to have to undertake political decision-making, with consequences for a society, for a people, indeed, for world peace. Jaruzelski had to make decisions under non-democratic circumstances. Jaruzelski will be treated here as a case study.

Wojciech Jaruzelski is a fascinating figure in part because, at first, he does not fascinate. He is the only General-Dictator produced by the communist world, a Leninist Bonaparte who nevertheless does not correspond to the expectations one might have for such a figure. He was not so much a social climber as a social dropout from an aristocratic family. His socialization was, as a matter of course, Catholic and nationalistic. He was more the type of a turncoat from the ranks of the ancien régime. The messages he promulgated as minister, head of government, party leader and head of state had nothing electrifying about them. He proclaimed no ideology; his words mobilized no emotion. His message was always "duty" and "fulfillment of duty." And, indeed, his career was largely one that was foisted upon him - most often he declined the offers made to him. To be sure, he turned down these offers only in order to yield to the demands of others that it was his duty to be minister or party leader. The rank of marshal was the only one he had successfully turned down time and again, for here, probably no one could have convinced him that this had anything to do with duty. Besides, the image of another marshal would have been overwhelming - that of Marshal Jozef Pilsudski, who cast an ambivalent shadow over all of modern Poland. (Rosenberg 1995; 125, 177).

The figure of the man in dark glasses with the stiff, military bearing and ascetic personal lifestyle does not invite "populist" identifications. Jaruzelski is most certainly not the leader onto whom the expectations and longings of the masses can be projected. His dictatorship has often been described as "socialism without a face," in critical distinction from the "socialism with a human face" promised by 
the Spring of Prague. Jaruzelski stands for no inspiring ideas, no mobilizing message.

This book will discuss and explore the decisive question for any systematic evaluation of Jaruzelski, that is, whether or not the imposition of martial law was really, as Jaruzelski himself claimed, the only means by which to avoid a Soviet invasion. This question is the point of departure for the actual topic: the compatibility of leadership and democracy. This question leads to the central theses of this book:

Thesis I: that political leadership always means having to choose the lesser of several identifiable evils;

Thesis II: that the inner logic of democracy leads to the narrowing and, ultimately, to the destruction of the playing field of political leadership.

This book is thus a book on the compatibility of democracy and political leadership. In this context, the term "leadership" will be preferred to the German term "Führung" for one reason, in accordance with the international discussion of political science: "Leadership" is accepted as a neutral term in the general scientific debate, even in the sense of a nonideological theoretical discourse. "Führung," on the other hand, carries the strong connotation of a variant of elitist theory bearing a positive valence in fascism, including the National Socialist principle of the "Führer."

Yet if "Führung" in the sense of "leadership" is inextricably connected with politics, then any tension that is claimed to exist between democracy and leadership must also include a tension between democracy and politics per se; then the entry into democracy is the beginning of the departure from politics.

Even a cursory consideration of this assumption reveals it to be at odds with political reality for several reasons:

- In stable democracies, politics is increasingly perceived as a competition between individuals who lay claim to leadership for themselves. This indicates more an alternate meaning than a diminishing of leadership.

- The findings of empirical social research and the claims of elite theory have led to a "realistic" understanding of democracy that stems from the unavoidability of democratic elites. 
These objections make it necessary to differentiate between concepts of leadership - if political leadership is equated with the carrying out of political office, then the above objections must be accepted and the hypothesis must be seen as mistaken from the outset. If, however, one employs the typology suggested by James MacGregor Burns (Burns 1978) in order to differentiate between different concepts of leadership, then suddenly more arguments are found to support the hypothesis.

A concept of leadership that is unlimited by specificity, one which includes reference to all those who hold office and carry out political function makes sense, of course, for all sorts of empirical analyses of comparative political science - studies on aspects of socialization, recruitment, marketing and the acceptance of political leaders have, of course, their own redeeming value. For an approach based on the theory of democracy, as in the theses formulated above, we must differentiate between a broad, general concept of leadership based on functions and offices, and a narrower concept that marks the decisive criterion of leadership, that is to say, the effects of political action that we can recognize, describe, measure, and analyze.

Leadership is therefore not understood in terms of function or roles, but in terms of effect. The fact that someone is Chancellor of the Federal Republic of Germany or Prime Minister of Japan does not in and of itself make that person a leader. Not until that person (whether Chancellor or éminence grise) undeniably and unmistakably "makes history" is he or she a leader. Others, those who merely carry out the duties of their office, are, or at least tend to be, replaceable, when understood solely in terms of their office. But with that, the central theses of this book include the claim that the notion that history is created by people can only hold true for a predemocratic stage of development.

The question remains to be answered, why, then, leadership as a product is so much in demand, why, even in stable democracies worldwide the call is heard for more and more leadership. The need for leadership strangely contradicts the triumphant advance of liberal democracy: on the one hand, this success of existing democracy is applauded; on the other hand, a central result of this success of democracy is feared and criticized-the erosion of leadership. This study, then, will also address this contradiction.

It is undoubtedly true that people "make" history. In a democracy, however, these individuals lose their identity and instead, assume roles, holding functions that are defined on the political market and are, indeed, must, in this sense be neutral with regard to individuality. 
This becomes clear when the extreme opposite of the actual existing democracy of the twentieth century is manifested: the forms of totalitarian dictatorship. Their style of leadership is completely different from that of democratic leadership with its roles and functionaries. One task of this book will be to demonstrate that this phenomenon has to do with content, and that this is one indication of the plausibility of the book's two central theses.

Wojciech Jaruzelski's role will continue to be controversial because he, as party leader in a communist dictatorship during the twilight of the Soviet-type systems neither had to nor was able to follow any certain role model. Jaruzelski intervened in the history of his country, and it was clear to him that he would, in his own words, "get his hands dirty" in the process. But denying this responsibility would have, in a certain sense, seemed to him even dirtier, like a flight from the responsibility of whose ethical dimension he was probably well aware.

His example is that of the exercise of personal influence on the fates of a large number of other people. He was only able to have this importance for Poland and for Europe because he made a choice between "evil" and "evil" and acted accordingly. The amount of power he had at his disposal would have been inadmissible in a democracy. Yet, when democracy triumphed in Poland eight years after the imposition of martial law, it triumphed in part also because Jaruzelski had helped to bring it about. With that, however, the power of General Jaruzelski came to an end. It had simply rationalized itself away, or rather, he had rationalized it away. The leadership with which he had violently suppressed the democratic movement in 1981 had dissolved into democracy. 


\section{Bibliography}

AGNOLI 1968: Johannes Agnoli, Peter Brückner: Die Transformation der Demokratie. Frankfurt am Main.

ALMOND, POWELL 1966: Gabriel Almond, G.Bingham Powell, Jr.: Comparative Politics. A developmental approach. Boston.

AMBROSE 1991: Stephen E. Ambrose: Nixon. Vol.III. Ruin and Recovery 19731990. New York.

APTHEKER 1951-1974: Herbert Aptheker: A Documentary History of the Negro People in the United States. IV Vol. New York.

ARENDT 1968: Hannah Arendt: Men in Dark Times. New York.

ARENDT 1987: Hannah Arendt: Wahrheit und Lüge in der Politik. Zwei Essays. München.

ARENDT 1989: Hannah Arendt: Die Krise des Zionismus. Essays und Kommentare 2. Berlin.

ARENDT 1995: Hannah Arendt: Rahel Varnhagen. Lebensgeschichte einer deutschen Jüdin aus der Romantik. München.

ARENDT 1995: Hannah Arendt: Eichmann in Jerusalem. Ein Bericht von der Banalität des Bösen. München.

ASH 1984: Timothy Garton Ash: The Polish Revolution. Solidarity. New York.

ATWOOD 1987: Margaret Atwood: The Handmaid's Tale. New York.

BACHMANN 1995: Klaus Bachmann: Poland. In: Hanspeter Neuhold et al. (eds.): Political and Economic Transformation in East Central Europe. Boulder, 37-55.

BACHRACH 1967: Peter Bachrach: The Theory of Democratic Elitism. A Critique. Boston.

BARNES 1990: Julian Barnes: A History of the World in $101 / 2$ Chapters. London.

BEAUVOIR 1968: Simone de Beauvoir: Force of Circumstance. Harmondsworth.

BERNHARD, SZLAJFER 1995: Michael Bernhard, Henryk Szlajfer (eds.): From the Polish Underground. Selections from Krytyka, 1978 - 1993. University Park (PA). 
BEYME 1994: Klaus von Beyme: Systemwechsel in Osteuropa. Frankfurt am Main.

BLAKE 1969: Robert Blake: Disraeli. London.

BLONDEL 1987: Jean Blondel: Political Leadership. Towards a General Analysis. London.

BRUS 1982: Wlodzimierz Brus et al.: „Normalisierungsprozesse” im sowjetisierten Mitteleuropa. Ungarn, Tschechoslowakei, Polen. Forschungsprojekt Krisen in den Systemen sowjetischen Typs, geleitet von Zdenek Mlynar. Studie Nr.1.

BÜCHELE 1993: Herwig Büchele: SehnSucht nach der Schönen neuen Welt. Thaur, Tirol.

BURNHAM 1943: James Burnham: The Machiavellians. Defenders of Freedom. New York.

BURNS 1978: James MacGregor Burns: Leadership. New York.

CHAMBERLAIN 1922: Houston Stewart Chamberlain: Die Grundlagen des XIX. Jahrhunderts. München.

CHARMLEY 1993: John Charmley: Churchill. The End of Glory. A Political Biography. Sevenoaks, Kent.

CONQUEST 1968: Robert Conquest: The Great Terror. Stalin's Purge of the Thirties. Harmondsworth.

COOLE 1988: Diana H.Coole: Women in Political Theory. From Ancient Misogony to Contemporary Feminism. Boulder.

CROSSMANN 1949: Richard Crossman (ed.): The God That Failed. New York.

DAHL 1956: Robert A.Dahl: A Preface to Democratic Theory. Chicago.

DAHL 1989: Robert A.Dahl: Democracy and Its Critics. New Haven.

DE GRAZIA 1989: Sebastian de Grazia: Machiavelli in Hell. Princeton.

DOWNS 1957: Anthony Downs: An Economic Theory of Democracy. New York.

EASTON 1953: David Easton: The Political System. An Inquiry into the State of Political Science. New York.

EDELMAN 1985: Murray Edelman: The Symbolic Uses of Politics. Urbana, Illinois.

ELIAS 1987: Norbert Elias: Engagement und Distanzierung. Arbeiten zur Wissenssoziologie I. Frankfurt am Main. 
ETTINGER 1995: Elzbieta Ettinger: Hannah Arendt. Martin Heidegger. Eine Geschichte. München.

FALIN 1993: Valentin M.Falin: Politische Erinnerungen. München.

FEST 1973: Joachim C.Fest: Hitler. Eine Biographie. Frankfurt am Main.

FINER 1976: S.E.Finer: The Man on Horseback. The Role of Military in Politics. Harmondsworth.

FISCHER 1969: Ernst Fischer: Erinnerungen und Reflexionen. Reinbek.

FITZGIBBON 1977: Louis Fitzgibbon: Katyn Massacre. London.

FRAENKEL 1964: Ernst Fraenkel: Deutschland und die westlichen Demokratien. Stuttgart.

FRAENKEL 1974: Ernst Fraenkel: Der Doppelstaat. Frankfurt am Main.

FRANKLIN 1980: John Hope Franklin: From Slavery to Freedom. A History of Negro Americans. New York.

FREY 1983: Bruno S.Frey: Democratic Economic Policy. A Theoretical Introduction. Oxford.

FUEGI 1995: John Fuegi: The Life and Lies of Bertolt Brecht. London.

GANDHI 1957: Mohandas K.Gandhi: An Autobiography. The Story of My Experiments With Truth. Boston.

GILMAN 1979: Charlotte Perkins Gilman: Herland. London.

GOLDMAN 1994: Peter Goldman et al.: Quest for the Presidency 1992. College Station (Texas).

GORBACHEV 1995: Mikhail Gorbachev: Erinnerungen. Berlin.

GUÉHENNO 1994: Jean-Marie Guéhenno: Das Ende der Demokratie. München.

HAFFNER 1978: Sebastian Haffner: Anmerkungen zu Hitler. München.

HALBERSTAM 1972: David Halberstam: The Best and the Brightest. New York.

HAMILTON, MADISON, JAY: On the Constitution. Selections from the Federalist Papers. New York (1954).

HENNIS 1973: Wilhelm Hennis: Die mißverstandene Demokratie. Demokratie - Verfassung - Parlament. Studien zu deutschen Problemen. Freiburg im Breisgau.

HILL 1979: Melvyn A.Hill (ed.): Hannah Arendt. The Recovery of the Public World. New York. 
HIRSCH 1969: Helmut Hirsch: Rosa Luxemburg in Selbstzeugnissen und Bilddokumenten. Reinbek.

HIRSCH 1993: Helga Hirsch: Die Russen wollten gar nicht einmarschieren. In: Die Zeit, 50/1993, 10.Dezember, 98.

HODGSON 1980: Godfrey Hodgson: All Things to All Men. The False Promise of the Modern American Presidency. New York.

HUXLEY 1985: Aldous Huxley: Ape and Essence. London.

ISAACSON 1992: Walter Isaacson: Kissinger. A Biography. London.

JARUZELSKI 1992: Wojciech Jaruzelski: Das war psychische Folter. Interview. Der Spiegel, 20/1992.

JARUZELSKI 1993: Wojciech Jaruzelski: Mein Leben für Polen. Erinnerungen. Mit einem Gespräch zwischen Wojciech Jaruzelski und Adam Michnik. München.

JARUZELSKI 1996: Wojciech Jaruzelski: Hinter den Türen der Macht. Der Anfang vom Ende einer Herrschaft. Leipzig.

JOLY 1990: Maurice Joly: Ein Streit in der Hölle. Gespräche zwischen Machiavelli und Montesquieu über Macht und Recht. Frankfurt am Main.

KATZENSTEIN 1996: Peter J. Katzenstein: Cultural Norms and National Security. Police and Military in Postwar Japan. Ithaca.

KEARNS 1976: Doris Kearns: Lyndon Johnson and the American Dream. New York.

KEARNS GOODWIN 1987: Doris Kearns Goodwin: The Fitzgeralds and the Kennedys. An American Saga. New York.

KELSEN 1963: Hans Kelsen: Vom Wesen und Wert der Demokratie. Aalen.

KENNEDY 1956: John F.Kennedy: Profiles in Courage. New York.

KIMBALL 1997: Warren F.Kimball: Forged in War. Roosevelt, Churchill, and the Second World War. New York.

KISSINGER n.d.: Henry A.Kissinger: A World Restored. Metternich, Castlereagh and the Problems of Peace 1812-1822. Boston.

KISSINGER 1979: Henry A.Kissinger: White House Years. Boston.

KISSINGER 1994: Henry A. Kissinger: Diplomacy. New York.

KNOLL 1962: August Maria Knoll: Katholische Kirche und scholastisches Naturrecht. Zur Frage der Freiheit. Wien.

KOESTLER 1947: Artur Koestler: Darkness at Noon. London.

KOESTLER 1964: Artur Koestler: The Yogi and the Commissar. London. 
KUBINA 1995: Michael Kubina u.a.: „Hart und kompromißlos durchgreifen." Die SED contra Polen 1980/81. Geheimakten der SED-Führung über die Unterdrückung der polnischen Demokratiebewegung. Berlin.

LABEDZ 1984: Leopold Labedz (ed.): Poland under Jaruzelski. A Comprehensive Sourcebook on Poland during and after Martial Law. New York.

LANGBEIN 1980: Hermann Langbein: ....nicht wie die Schafe zur Schlachtbank. Widerstand in den nationalsozialistischen Konzentrationslagern. Frankfurt am Main.

LA PALOMBARA 1987: Joseph La Palombara: Democracy Italian Style. New Haven.

LEHMBRUCH 1967: Gerhard Lehmbruch: Proporzdemokratie. Politisches System und politische Kultur in der Schweiz und in Österreich. Tübingen.

LIPSET 1960: Seymour Martin Lipset: Political Man. The Social Bases of Politics. New York.

LOPINSKI 1990: Maciej Lopinski et al.: Konspira. Solidarity Underground. Berkeley.

LUXEMBURG 1970: Rosa Luxemburg: Schriften zur Theorie der Spontaneität. Reinbek.

MACHIAVELLI 1952: The Prince. Translated by Luigi Ricci revised by E.R.P. Vincent. New York.

MAIER 1997: Charles S.Maier: Dissolution. The Crisis of Communism and the End of East Germany. Princeton.

MANCHESTER 1984: William Manchester: The Last Lion. Winston Spencer Churchill. Visions of Glory. 1874-1932. London.

MANCHESTER 1989: William Manchester: The Last Lion. Winston Spencer Churchill. Alone. 1932-1940. New York.

MANNHEIM 1958: Karl Mannheim: Mensch und Gesellschaft im Zeitalter des Umbaus. Darmstadt.

MANNHEIM 1978: Karl Mannheim: Ideologie und Utopie. Frankfurt am Main.

MAREK 1970: Franz Marek: Was Stalin wirklich sagte. Wien.

MARIUS 1984: Richard Marius: Thomas More. A Biography. New York.

MC CULLOUGH 1992: David McCullough: Truman. New York.

MC NAMARA 1995: Robert S.McNamara: In Retrospect. The Tragedy and Lessons of Vietnam. New York. 
MC PHERSON 1991: James M.McPherson: Abraham Lincoln and the Second American Revolution. New York.

MICHNIK 1985: Adam Michnik: Letters from Prison and Other Essays. Berkeley.

MILLER 1983: Nathan Miller: F.D.R. An Intimate History. New York.

MLYNAR 1978: Zdenek Mlynar: Nachtfrost. Erfahrungen auf dem Weg vom realen zum menschlichen Sozialismus. Frankfurt am Main.

MLYNAR 1990: Zdenek Mlynar: Can Gorbachev Change the Soviet Union? Boulder.

MORGENTHAU 1958: Hans J.Morgenthau: Dilemmas of Politics. Chicago.

MÜNKLER 1984: Herfried Münkler: Machiavelli. Die Begründung des politischen Denkens der Neuzeit aus der Krise der Republik Florenz. Frankfurt am Main.

NARR/NASCHOLD 1971: Wolf-Dieter Narr, Frieder Naschold: Theorie der Demokratie. Einführung in die moderne politische Theorie. Teil III. Stuttgart.

NETTL 1967: Peter Nettl: Rosa Luxemburg. Köln.

OLSON 1965: Mancur Olson: The Logic of Collective Action. Public Goods and the Theory of Groups. Cambridge (MA)

PAULEY 1997: Bruce Pauley: Hitler, Stalin, and Mussolini. Totalitarianism in the Twentieth Century. Wheeling (IL).

PELINKA 1974: Anton Pelinka: Dynamische Demokratie. Zur konkreten Utopie gesellschaftlicher Gleichheit. Stuttgart.

PFABIGAN 1976: Alfred Pfabigan: Karl Kraus und der Sozialismus. Eine politische Biographie. Wien.

PLASSER 1987: Fritz Plasser: Parteien unter Streß. Zur Dynamik der Parteiensysteme in Österreich, der Bundesrepublik Deutschland und den Vereinigten Staaten. Wien.

POLAND UNDER MARTIAL LAW 1983: Poland Under Martial Law. A Report on Human Rights by the Polish Helsinki Watch Committee. English edition by the U.S. Helsinki Watch Committee.

POLSBY 1983: Nelson W. Polsby: Consequences of Party Reform. Oxford.

POPPER 1970: Karl Popper: Die offene Gesellschaft und ihre Feinde. 2 Bände. Bern.

PUMBERGER 1989: Klaus Pumberger: Solidarität im Streik. Politische Krise, sozialer Protest und Machtfrage in Polen 1980/81. Frankfurt am Main. 
RADZINSKY 1996: Edvard Radzinsky: Stalin. New York.

RICHARDSON/FLANAGAN 1984: Bradley M.Richardson, Scott C. Flanagan: Politics in Japan. Boston.

RIESMAN 1950: David Riesman: The Lonely Crowd. A Study of the Changing American Character. New Haven.

RIKER 1982: William H.Riker: Liberalism against Populism. A Confrontation Between the Theory of Democracy and the Theory of Social Choice. Prospect Heights (IL)

ROSENBERG 1995: Tina Rosenberg: The Haunted Land. Facing Europe's Ghosts after Communism. New York.

SALISBURY 1993: Harrison E.Salisbury: The New Emperors. Mao and Deng. A Dual Biography. London.

SARTRE 1960: Jean-Paul Sartre: Betrachtungen zur Judenfrage. In: Drei Essays. Berlin (West).

SCHAUSBERGER 1978: Norbert Schausberger: Der Griff nach Österreich. Der Anschluß. Wien.

SCHUMPETER 1972: Joseph A.Schumpeter: Kapitalismus, Sozialismus und Demokratie. München.

SEGEV 1993: Tom Segev: The Seventh Million. The Israelis and the Holocaust. New York.

SEMPRUN 1991: Jorge Semprun: Netschajew kehrt zurück. Berlin.

SERENY 1995: Gitta Sereny: Albert Speer. His Battle with Truth. New York.

SHEVARDNADZE 1991: Edvard Shevardnadze: Die Zukunft gehört der Freiheit. Reinbek.

SHIRER 1982: William L.Shirer: Gandhi. A Memoir. London.

SHULL 1991: Steven A.Shull (ed.): The Two Presidencies. A Quarter Century Assessment. Chicago.

SLATER 1985: Ian Slater: Orwell. The Road to Airstrip One. New York.

SMOLNAR 1989: Alexander Smolnar, Pierre Kende: Die Rolle oppositioneller Gruppen. Am Vorabend der Demokratisierung in Polen und Ungarn (1987-1989). Forschungsprojekt Krisen in den Systemen sowjetischen Typs, geleitet von Zdenek Mlynar, Studie Nr. 17-18.

SPEER 1969: Albert Speer: Erinnerungen. Frankfurt am Main.

STEINER 1974: Jürg Steiner: Amicable Agreement versus Majority Rule. Conflict Resolution in Switzerland. Chapel Hill. 
SUN TZU n.d.: Sun Tzu on the Art of War. The oldest Military Treatise in the World. Translated from the Chinese with introduction and critical notes by Lionel Giles.

TALMON 1986: J.L.Talmon: The Origins of Totalitarian Democracy. Harmondsworth.

TALOS, NEUGEBAUER 1984: Emmerich Talos, Wolfgang Neugebauer (eds.): „Austrofaschismus". Beiträge über Politik, Ökonomie und Kultur. Wien.

TEXTE 1975: Texte zur katholischen Soziallehre, herausgegeben vom Bundesverband der Katholischen Arbeitnehmer-Bewegung (KAB) Deutschlands, Kevalaer.

THEWELEIT 1980: Klaus Theweleit: Männerphantasien. 2 Bände. Reinbek.

TRUNK 1972: Isaiah Trunk: Judenrat. The Jewish Councils in Eastern Europe under Nazi Occupation. New York.

ULAM 1989: Adam B.Ulam: Stalin. The Man and His Era. Boston.

WEBSTER 1990: Paul Webster: Pétain's Crime. The full story of French Collaboration in the Holocaust. London.

WEISBROT 1991: Robert Weisbrot: Freedom Bound. A History of America's Civil Rights Movement. New York.

WILSFORD 1995: David Wilsford (ed.): Political Leaders of Contemporary Western Europe. Westport, Connecticut.

WOODS 1995: Randall Bennett Woods: Fulbright. A Biography. Cambridge (UK).

YIVO 1972: Yivo Institute for Jewish Research (ed.): Imposed Jewish Governing Bodies Under Nazi Rule. New York.

ZAHN 1964: Gordon C.Zahn: In Solitary Witness. The Life and Death of Franz Jägerstätter. Springfield (IL)

ZELIKOW, RICE 1995: Philip Zelikow, Condoleezza Rice: Germany Unified and Europe Transformed. A Study in Statecraft. Cambridge (MA).

ZELMAN 1995: Leon Zelman: Ein Leben nach dem Überleben. Aufgezeichnet von Armin Thurner. Wien.

ZOHN 1971: Harry Zohn: Karl Kraus. New York. 